This is an Accepted Manuscript of an article published by Taylor \& Francis Group in Planning Perspectives on 29 Oct 2017, available online: http://www.tandfonline.com/10.1080/02665433.2017.1393627

Wright V, Kearns A, Abrams L \& Hazley B (2019) Planning for play: seventy years of ineffective public policy? The example of Glasgow, Scotland. Planning Perspectives, 34 (2), pp. 243-263.

\title{
Planning for Play: Seventy years of ineffective public policy? The example of Glasgow, Scotland.
}

\section{Abstract}

This paper looks at the planning and provision of outdoor play spaces for children over a seventy year period since the Second World War. Using Glasgow as a case study, the paper examines whether and how research on families and children living in flats has been used to inform national and local planning policies in this area, and in turn how well policy is converted into practice and provision on the ground. The paper considers these issues in four time periods: the period of postwar reconstruction and development from the late 1940s to the early 1970s, when large amounts of social housing, much of it in the form of flats, was built; the period of decline and residualisation of social housing in the 1970s and 1980s; the 1990s and 2000s when several attempts were made to regenerate social housing estates; and the last five years, during which time the Scottish Government has developed a number of policies concerning children's health and physical activity, and for the development of sustainable, healthy places. While it may have been the case that there were other priorities in Glasgow, or that provision for play did not feature in the planning agenda, nevertheless planning policy in Glasgow appears to have been ineffective when examined across several decades. Issues such as a weak link between research and policy recommendations, unresolved tensions between a number of policy options, and a lack of political priority afforded to the needs to children are identified as contributory factors.

\section{Introduction}

One would hope that in the early $21^{\text {st }}$ century, the planning and provision of outdoor spaces for children's play in our cities would be better than it was in the last century. Fundamentally, there has been an expansion of research to understand how children interact with and use their surrounding environments, in order to inform planning and design policies. Such development in research and rights might have been expected to lead to greater provision for outdoor play. In particular, 'children's geographies studies in the 1990s were instrumental in contributing to a growing understanding of young people's use of local spaces'. ${ }^{1}$ However, variation between cities and countries mean that it is still the case that 'a better understanding of where children play and why, is important ...'.2

If on the one hand this development points in a positive direction with regard to planning for children's outdoor space and play, we must also recognise several forces which push in the opposite direction. Globalisation, mobile capital and marketization are identified as operating to produce deregulation, state withdrawal from service provision and disinvestment in places at short notice so that 'cities are shaped by forces that operate at global and national levels'. ${ }^{3}$ Social change from the 1950s onwards has meant that children's outdoor play has also become more home-centred and institutionalised through organised activities supervised or controlled by adults/parents who are concerned for their children's safety. ${ }^{4}$ This permits the argument that greater play provision will not

\footnotetext{
${ }^{1}$ Percy-Smith, 'Negotiating active citizenship',12.

${ }^{2}$ Veitch et al, 'Where do children usually play?', 384.

${ }^{3}$ van Vliet and Karsten, 'Child-Friendly Cities in a Globalizing World', 4.

${ }^{4}$ Valentine and McKendrick, 'Children's outdoor play'; Thomson, Lost Freedom.
} 
result in more outdoor play, although others argue that although 'playing outside has lost its dominant character', at least in western cities, 'outdoor children' can still be found in relatively quiet, more homogenous neighbourhoods. ${ }^{5}$ Further, spatial constraints such as increased traffic and reduced spaces to play vary between neighbourhoods in the same city. ${ }^{6}$ Lastly, it is contended that children's use of local spaces is often marginalised by inadequate provision, exclusion from decisionmaking and the stigmatising of their behaviours. ${ }^{7}$ For Percy-Smith, 'intolerance of children's use of space ... reflects their position as "less than citizens"'. 8

\section{Studying Play Provision in Glasgow}

Given these countervailing factors supporting or negating the case for better provision of outdoor space over time for children to interact and play in, we are interested to take a historical perspective on outdoor play provision for children in the city of Glasgow, Scotland, to determine whether there has been continuity or change in policy and provision over the last half century. The value of this approach has been demonstrated by Karsten in the case of children's play in Amsterdam, where she showed that it could not necessarily be argued that 'it all used to be better' in the post-war years. ${ }^{9}$ Glasgow is a particularly apposite case-study in this respect for a number of reasons. First and foremost, Glasgow has an unusually high percentage of flats for a British city: $73 \%$ of households currently live in flats, including $7 \%$ in buildings of six storeys or more. ${ }^{10}$ Concerns about restricted play opportunities for children living in flats have existed for a long time, focusing primarily on consequences in terms of behavioural problems in children and heightened anxiety among parents about lack of safe play areas. ${ }^{11}$

Glasgow is also a relatively poor, deprived city, which raises a question about whether families can afford to participate in the shift to organised and institutionalised play (in for example Soft Play Centres and Sports Centres which require an admission fee) that provides cultural capital (learning a particular sport, mixing with children from similar class background) but is more expensive than outdoor play. ${ }^{12}$ Another central underlying concern is that Glasgow has relatively poor health by European standards, with discussion of a 'Glasgow Effect' upon mortality. ${ }^{13}$ Over a quarter $(27 \%)$ of children in the city do not meet the recommended level of daily physical activity (60 minutes) with a fifth (22\%) of children being overweight at age five in the most deprived areas and an annual rise in childhood obesity of $0.4 \%$ per annum. ${ }^{14}$ The importance of outdoor play in residential areas is highlighted by the observation that education authorities in Scotland have difficulty meeting the Government's guideline of two hours physical education for children per week, thus 'emphasising

\footnotetext{
${ }^{5}$ Karsten, 'It all used to be better?', 283-4.

${ }^{6}$ Karsten 'It all used to be better?'.

7 Percy-Smith, 'Children's Participation in Local Decision Making'.

${ }^{8}$ Percy-Smith, 'Negotiating active citizenship', 11.

${ }^{9}$ Karsten, 'It all used to be better?'.

${ }^{10}$ Scottish House Condition Survey 2013, specially requested tabulations.

${ }^{11}$ Gittus, Flats, Families and the Under Fives; Richman, 'The Effects of Housing on Pre-school Children and their Mothers'.

${ }^{12}$ Valentine and McKendrick, 'Children's outdoor play'.

${ }^{13}$ Walsh et al, 'It's not 'just deprivation', Walsh et al, History, politics and vulnerability.

${ }^{14}$ Understanding Glasgow: http://www.understandingglasgow.com/; NHSGGC 2011 'Child Health Weight'.
} 
the importance of non-curricular physical activity'. ${ }^{15}$ The health sector's interest in childhood obesity, diet and physical activity pertains to a further development which may affect whether policy provision for children's outdoor play has changed over time - powers covering health, social services and the environment were devolved under the Scotland Act (1998). Prior to this, Glasgow was subject to UK-wide guidance and regulations on planning as implemented by the Scottish Office, which gave 'Scottish administration a distinctive character'. ${ }^{16}$

Our interest is in how the planning and provision of outdoor play spaces for children in Glasgow has changed since the Second World War. In what follows, we address this in four time periods. First, the period of post-war reconstruction and development from the late 1940s to early 1970s. Second, the period of council housing decline from the late 1970s through the 1980s, when conditions deteriorated and new construction was limited. Third, the period of regeneration and redevelopment in the 1990s and 2000s, when large-scale regeneration programmes were mounted in respect of several deprived estates. Finally, we consider the last five years up to the present day when there has been a lot of strategy development in relation to play and play spaces in Scotland. Although the balance varies, for each time period we have looked at evidence about the quantity and quality of children's play spaces in the city, reviewed research findings about how children live and play in residential environments, and considered any relevant policy developments. In all periods we will consider policy relating to outdoor play and provision in relation to the dominant planning concerns in the city. Thereafter, in the discussion, we consider change and continuity over time and consider potential explanations for our findings.

\section{Post War Reconstruction and Development in the late 1940s to early 1970s}

The provision of play space was not a major priority in Glasgow in the three decades following the Second World War. Glasgow Corporation arguably had more politically sensitive issues to consider such as the sheer scale of the city's housing shortage and overcrowding in the existing housing stock. In the immediate post war years, Glasgow was described as having the worst housing conditions in the UK. In the 1940s and 1950s political discourse centred on housing construction as a way of 'rebuilding' the nation. Glasgow Corporation embarked upon a programme of slum clearance and the provision of municipal housing. Glasgow's planned housing programme was extensive: 111,677 permanent corporation homes were built between 1945 and $1975 .{ }^{17}$ In the 1950 s four peripheral housing estates were constructed on greenfield sites, mostly comprising modern three storey tenement flats. Following early experimentation in the 1950s, in the early 1960s the Corporation adopted mass systems-built high-rise flats as a solution to the lack of space in the inner city. These were to be built in 29 Comprehensive Redevelopment Areas (more than any other city in the UK see Figure 1), in other gap sites in the inner city and in peripheral estates (Figure 2).

\footnotetext{
${ }^{15}$ NHSGGC, 2011, 2.

${ }^{16}$ Cullingworth, and Nadin, Town and Country Planning in the UK, 51.

${ }^{17}$ Glasgow District Council, Farewell to the Single-End, 57.
} 


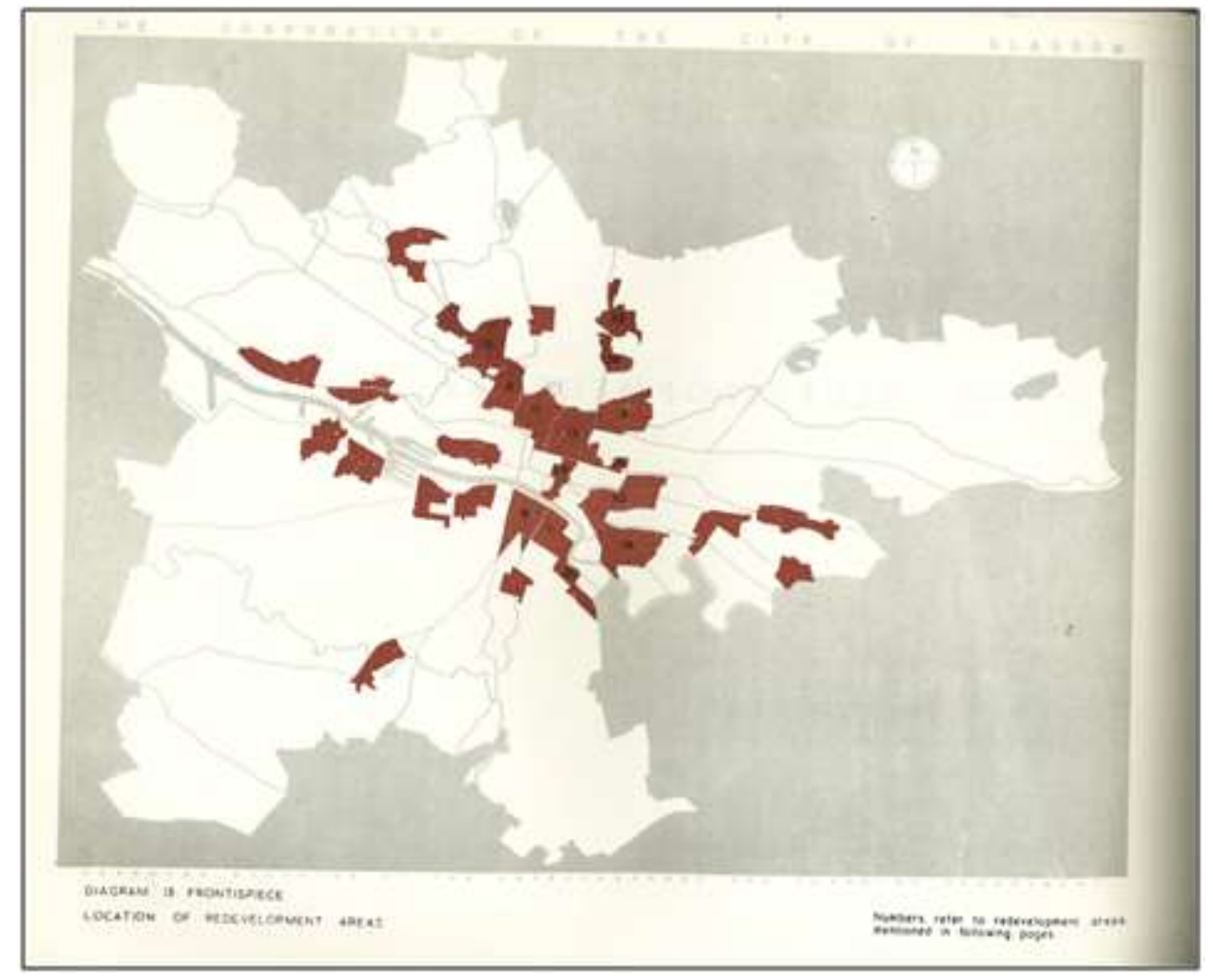

Figure 1: Glasgow's 29 Comprehensive Development Areas (CDAs), Glasgow Corporation, City of Glasgow Development Plan, 1960.

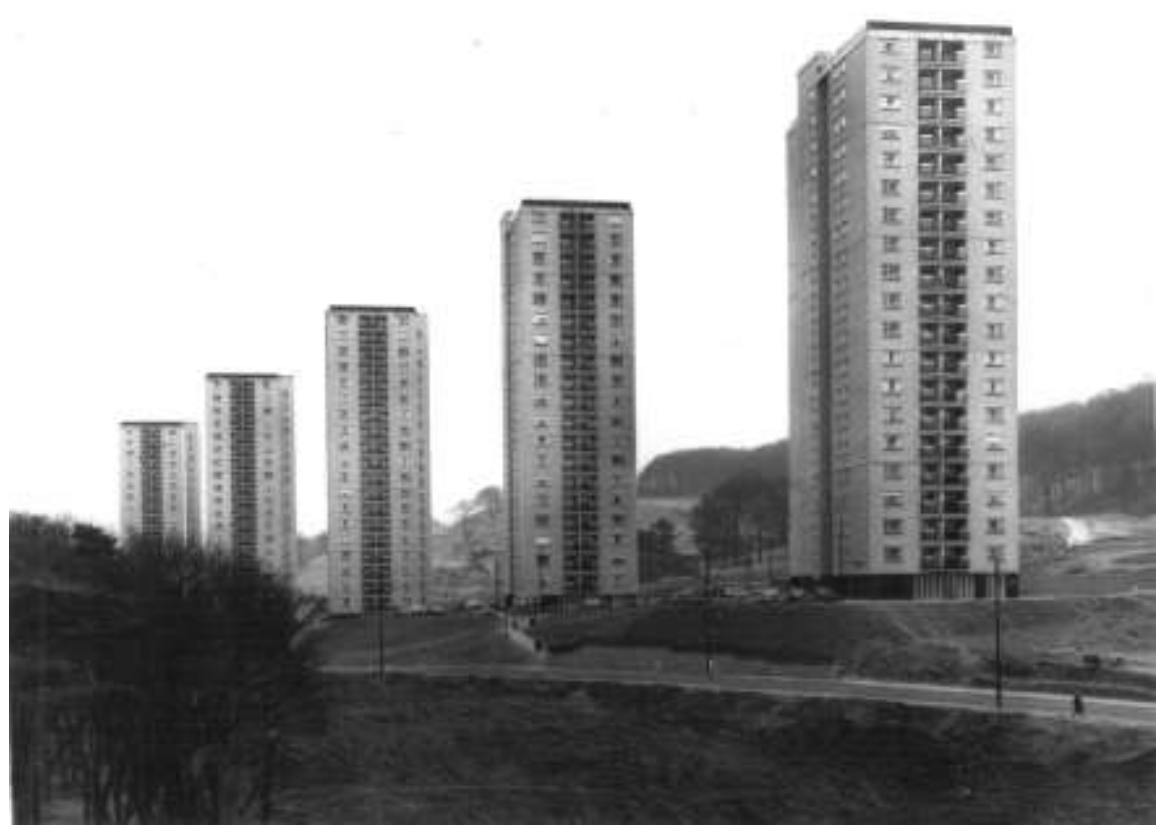

Figure 2: Mitchellhill Flats, Castlemilk (late 1960s), University of Glasgow Archive Services, Homes in High Flats Collection DC127/22a 
The construction of high-density flats enabled municipal authorities in the UK to rebuild the inner cities and reduce the size of the 'overspill' population (which would have resulted in a loss of revenue through rents and rates). ${ }^{18}$ But, for many commentators low density housing, crucially with gardens, would have been preferable for families with young children. Early on in this period, Margaret Willis, writing on behalf of the Flats Sub-Committee of the Central Housing Advisory Committee in 1952, suggested that 'the need most keenly felt' by mothers living in flats was for 'somewhere safe for the children to play'. She argued that it was children who were most restricted by life in flats and as a result 'one or more' children's play areas should be a priority in planning the space around blocks of flats on housing estates. ${ }^{19}$ Willis's report was an attempt to influence planning standards, as at this point there were no accepted standards for the inclusion of play spaces in housing estates. However, the aim was to 'Give the People Homes' ${ }^{20}$ The flats came first, not amenities such as children's play areas, churches, schools or even shops. There were limited funds and housing construction was the priority.

Many of Willis's recommendations were subsequently repeated in later reports in the 1960s and 1970s considering play facilities for children living in flats in the UK. The Ministry of Housing and Local Government's Homes for Today and Tomorrow of 1961 acted on her advice and set out space standards for children's play. ${ }^{21}$ Although the authors found it difficult to specify minimum standards based on the number of children living in or near an estate as this would vary over time. It was recommended that minimum standards for play space should be set at 20 to 25 square feet per person on the estate not counting people in one and two person dwellings. ${ }^{22}$ Significantly this allocation was to be made regardless of the availability of local parks as it was found that mothers preferred younger children to play near to their homes. ${ }^{23}$ Social researcher Joan Maizels came to similarly ignored conclusions regarding mandatory standards in her study of the experience of children between the ages of two and five living in high flats. ${ }^{24}$. Recommendations in the early 1970 s continued to echo those of the past two decades. In the late 1960s Glasgow was in the vanguard of mass housing and high rise construction in terms of the proportion built in the city. ${ }^{25}$ Pearl Jephcott conducted the largest study to date of multi-storey housing with children's play being a central focus. ${ }^{26}$ Over 1,300 adults were interviewed, drawn from the 163 high-rise blocks existing in the city in 1968 and 1969, which together contained 6,700 children aged under 14. Unsurprisingly Jephcott found that tenants were most dissatisfied by the delay in providing facilities on newly built high rise estates; in one instance an estate had five blocks of high flats and 'literally hundreds of small children' but had 'no suitable place' for the children to play for 'as long as four years'. ${ }^{27}$ She therefore reiterated the importance of the provision of play space and equipment, and of adult supervision to prevent bullying and vandalism. Indeed it had been suggested from the early 1960s that play provision would only be improved by increased expenditure on administration rather than

\footnotetext{
${ }^{18}$ Farmer and Smith, 'Overspill Theory'.

${ }^{19}$ Willis, Living in Flats, 10.

${ }^{20}$ Glendinning and Malthius, Towerblock, 220.

${ }^{21}$ MHLG, Homes for Today and Tomorrow, para 174.

${ }^{22}$ MHLG, Homes for Today and Tomorrow, para 189.

${ }^{23}$ MHLG, Homes for Today and Tomorrow, para 187.

${ }^{24}$ Maizels, Two to Five in High Flats, 26.

${ }^{25}$ Horsey, Tenements and Towers.

${ }^{26}$ Jephcott, Homes in High Flats, 80-100 and 137-138.

27 Jephcott, Homes in High Flats, 137.
} 
ground space; in other words investment in running costs rather than capital outlay. ${ }^{28}$ This contradiction remains at the heart of debates around provision for play, whether to invest in play equipment in the hope that children will use it, or to invest in adult supervision to assist in outdoor games and ensure that any existing equipment is not vandalised and is safe to use.

Glasgow Corporation's Director of Planning R. D. Mansley, responded to the criticisms of the city's high-density housing estates in $1971 .{ }^{29}$ There was a clear admission that 'standards of living' in Glasgow could be improved especially in terms of providing 'appropriate' housing for families with children. Mansley suggested that given the absence of private gardens on the high density estates constructed in the 1960s, an 'open space policy' was required for the city, which would encompass the provision of 'local open space' within residential areas to 'meet the special need of children who require play close to the supervision of mothers from the house' ${ }^{30}$ Further he admitted that the quality of landscaping in high density Corporation housing estates containing high rise blocks was poor when compared with the Scottish New Towns, and especially East Kilbride, where three to four times as much was spent on capital and maintenance. ${ }^{31}$ Planning for the needs of children was central to the ethos and development of new towns in Scotland as elsewhere in Britain, and by the early 1970s Glasgow wished to compete with its new town neighbours on this score. ${ }^{32}$

Rae recommended that 'the need for additional facilities in multi-storey flats should be emphasised', with the under-fives given priority. ${ }^{33}$ It was accepted that the play of older children and adults could be accommodated in existing local parks (in 1972 there were 24 public parks in the city encompassing an area of 1,948 acres).$^{34}$ This reliance on existing public parks, or Glasgow's reputation as the 'Dear Green Place'. ${ }^{35}$ Mansley set out space standards of 2.5 acres of local open space per 1,000 people (rather than per number of children or per number of family dwellings constructed), to include 0.5 acres of equipped play areas. However, a later review in 1975 concluded that this standardisation had resulted in mismatches between provision and local demand, resulting in later removal of amenities in some areas. There was a desire for standards to be more flexible. Again this remains a tension in the provision of play amenities and facilities, i.e. the population structure of a community will change and thus capital investment in equipment may be inefficient in the long term, whereas investment in administration could be more effective.

\section{Decline in the late 1970s and 1980s}

Over the next two decades, as elsewhere in the UK, council housing in Glasgow continued to be stigmatised and residualised. ${ }^{36}$ Glasgow had perhaps over-extended itself to solve the city's post-war

\footnotetext{
${ }^{28}$ Hole, Children's Play on Housing Estates, 34.

${ }^{29}$ Mansley, Development Plan Review.

${ }^{30}$ Mansley, Development Plan Review, 11.

${ }^{31}$ Mansely, Development Plan Review, Rae, Planning Policy Report.

${ }^{32}$ Smith, East Kilbride, Smith, Smith, 'Origins of Scottish New Town Policy', Farmer and Smith, 'Overspill Theory'.

${ }^{33}$ Mansley, Development Plan Review, 23 and 26.

${ }^{34}$ Rae, Planning Policy Report, 32.

${ }^{35}$ See https://peoplemakeglasgow.com/dear-green-place

${ }^{36}$ Forrest and Murie 1983, Residualisation and Council Housing.
} 
housing problems, with social rented housing stock increasing proportionately throughout the $1960 \mathrm{~s}$ and 70 s, reaching a peak of $66 \%$ of the city's housing stock by 1981 , higher than most other places in the UK. ${ }^{37}$ Consequently, loan repayments consumed a large share of rental income. As Glasgow's economic situation worsened and unemployment increased in the late 1970s and early 1980s, revenue through rents declined as rents were not increased in line with costs and inflation for many years. As a result, repairs and maintenance to housing and surrounding amenities were not made, exacerbating the decline in the built environment of council housing estates. A large scale survey of the Council's housing stock and tenants in 1985 reported that $44 \%$ of the stock required essential repairs and the second most common tenant complaint about their neighbourhood was poor facilities, including for children's play. ${ }^{38}$ An accompanying study reported that neighbourhood dissatisfaction was highest among occupants of flats. ${ }^{39}$

Tenants' views in Glasgow reflected those elsewhere at the time. A UK-wide study for the Department of the Environment (DoE) reported in 1981 that for households with dependent children above the first floor the 'problems of this minority' ( $3 \%$ of all families) were serious. ${ }^{40}$ Echoing earlier studies which emphasised the restrictions placed on children living in flats it was suggested that 'however enterprising the allocation and transfer policies of local authorities, many thousands of young children and their parents will continue in inner areas to live in flats above the ground' ${ }^{41}$ Furthermore, it was stated that few facilities had been provided in the past two decades 'as compensation for flat life', with housing departments having 'been little involved in how to alleviate the particular problems of their tenants in multi-storey accommodation' ${ }^{42} \mathrm{~A}$ decade later the British Medical Journal's assistant editor Stella Lowry reiterated that 'children living in flats often have few opportunities for normal play', with games being forbidden on the 'large expanses of grass surrounding flats with there being little enclosed space for children to play safely. ${ }^{43}$ She concluded that 'most mothers prefer to keep their children indoors'. Voluntary organisations were at the forefront in running play groups for young children, groups for older children and community facilities for the whole family. No recommendations were made relating to standards for play as there seemed to be an acceptance that the authorities were focused on transferring families from flats to houses rather than improving the existing facilities for play.

Much more so than the rest of the UK however, Glasgow continued to house a large number of families in flats. The 1985 housing survey revealed that a quarter of the city's households were families with dependent children, including $30 \%$ of the occupants of tenement flats and $11 \%$ of the occupants of tower and deck-access blocks. ${ }^{44}$ Thus, problems of play for children in flats, reported across the UK, were more pressing in Glasgow than elsewhere, exacerbated by faster economic decline in general as the city moved towards a post-industrial future..$^{45}$ In response, the first significant attempt at regeneration in the city occurred at this time. The Glasgow Eastern Area Renewal Project (GEAR) operated from 1976 to 1987 and was founded partly on central Government

\footnotetext{
${ }^{37}$ Crawford et al 2007, Will Glasgow Flourish? 19.

${ }^{38}$ Webster and Purkiss, House Condition Survey 1985 Volume 3.

${ }^{39}$ Satsangi et al, House condition survey 1985.

${ }^{40}$ Littlewood and Tinker, Families in Flats, 50.

${ }^{41}$ Littlewood and Tinker, Families in Flats, 51.

${ }^{42}$ Littlewood and Tinker, Families in Flats, 51.

${ }^{43}$ Lowry, 'Families and Flats', 245.

${ }^{44}$ Satsangi et al, House condition survey 1985.

${ }^{45}$ Lever, 'Deindustrialisation and postindustrial city'.
} 
criticisms that Glasgow Council was putting too many families into flats in areas with poor environments with poor social facilities. ${ }^{46}$ However, the final evaluation of GEAR found that through rehabilitation works, the project had most impact upon housing quality and physical environments in general, but 'had least impact upon the environment of local authority housing'. ${ }^{47}$

Instead in Glasgow an alternative development strategy to neighbourhood renewal focused on what can best be described as events-led regeneration as a way of 'reinventing' the city. Local government in Scotland was reorganised between 1973 and 1975 with the introduction of a two tier system: the formation of larger regional authorities and smaller district councils. The idea behind this was to promote 'efficiency and resource equalisation' which would assist in regional policy implementation. ${ }^{48}$ Crucially it was intended that Strathclyde Regional Council would act as a focus for funding from the European Community. This certainly became the case in the 1980s with the Glasgow Garden Festival in 1988 and Glasgow as European City of Culture in 1990. Both of these events marked the beginning of the attempted redevelopment of Glasgow economically, socially and culturally. Provision of improved facilities for children's outdoor play at a neighbourhood level was not a part of this strategy.

\section{Regeneration and Redevelopment in the 1990s and 2000s}

The last three decades have seen a series of attempts to regenerate Scotland's and Glasgow's deprived communities and social housing estates. Each regeneration programme has been different in its provenance, spatial focus and governance arrangements, but although there has been some attention paid to children, none of the programmes have included children's outdoor spaces and/or play as part of its objectives or monitoring criteria. Rather the priority was to physically improve housing stock in areas of high deprivation, which had resulted from Glasgow's post-industrial status and arguably the results of the failure of post-war regional planning in Scotland. ${ }^{49}$ The plan was that such physical improvement would lead to improvements in individual and community wellbeing.

In 1988, the New Life for Urban Scotland initiative was announced as a 'landmark in the history of regeneration in Scotland' with the aim of tackling multiple deprivation on Scotland's peripheral housing estates. The lessons learned from this initiative in the four study areas, including Castlemilk, in Glasgow, were to be incorporated into future policies. ${ }^{50}$ The strategy for Castlemilk included prioritising the needs of children and young people, in order to attractand retain economically active households. ${ }^{51}$ Yet, the interim evaluation of the initiative identified that residents' strongest and worsening dislikes about the areas around their homes included 'badly kept open spaces', litter, graffiti and vandalism. Moreover, four times as many people were concerned about having 'nowhere for kids to play' as those that thought there were 'good play areas for children' on the

\footnotetext{
${ }^{46}$ Wannop, 'The Glasgow Eastern Area Renewal (GEAR) Project'.

47 PIEDA, 'GEAR project evaluation', quoted in Wannop, 'The Glasgow Eastern Area Renewal (GEAR) Project', 463.

${ }^{48}$ Maver, Glasgow, 216.

${ }^{49}$ Collins and Levitt, 'The 'Modernisation' of Scotland'.

${ }^{50}$ Scottish Office, Progress in Partnership.

${ }^{51}$ Cambridge Policy Consultants, An evaluation of the New Life for Urban Scotland, 16.
} 
estate. ${ }^{52}$ The final evaluation of the programme some years later made no mention of children's outdoor play facilities, either in relation to aims for environmental improvements or improved community facilities. ${ }^{53}$

New Life for Urban Scotland was succeeded by the Social Inclusion Partnership programme in 1999, which adopted lessons from earlier approaches, and aimed to tackle both 'people' and 'place' issues, and to go further on community involvement and capacity. ${ }^{54}$ Of thethirty-four Partnerships established to tackle disadvantaged areas, nine were in Glasgow,. However there were no expectations that these partnerships would report on the quality of life of children, and there were no monitoring indicators related to children's play, neighbourhood quality or facilities for children. Similarly the replacement, Community Planning Partnerships, which were intended 'to deliver enhanced services to the most deprived neighbourhoods'. have been more successful in achieving the coordination of services providing regeneration than they have at engaging with communities and their priorities. ${ }^{55}$ Thus, while there was initial funding for projects for children and young people , there remained no consideration of this group in the evaluation of Community Planning Partnerships or recommendations for their future operation. ${ }^{56}$

Stock transfer of all 80,500 council dwellings to the newly formed Glasgow Housing Association (a not-for-profit company created by the then Scottish Executive) also aimed at taking a community focused approach to planning to improve the quality of life for residents. ${ }^{57}$ Glasgow Housing Association, in liaison with the City Council, devised and implemented a regeneration programme across fifteen areas of the city, comprising Transformational and Local Regeneration Areas. ${ }^{58}$ The goal of this programme was 'creating sustainable place transformation' but again, there was no specific focus on children and young people or play. Similarly Glasgow Housing Association's Neighbourhood Renewal Strategy funded a wider range of environmental and 'people-based' projects in areas where it was the major social housing provider. ${ }^{59}$ Within this was a planned expenditure of $£ 2.3 \mathrm{~m}$ over eight years (2005-12) on a Play Area Improvement Programme in partnership with the City Council 'in order to enhance local community facilities, provide safe play facilities ... and improve the local environment' ${ }^{60}$ The council owned the majority of the approximate 120 play areas in GHA housing neighbourhoods, which were 'either in need of major refurbishment' or 'effectively redundant'. ${ }^{61}$ Under a partnership agreement, the council was responsible for the maintenance of any play areas provided/redeveloped under the programme. This was the first time for decades that the city had implemented a city-wide programme for children's play areas, and 42 play areas were improved in the first five years. ${ }^{62}$

\footnotetext{
${ }^{52}$ O'Toole et al, Interim evaluation of the Castlemilk partnership, tables 4.2 and 4.3.

${ }^{53}$ Cambridge Policy Consultants, 1999.

${ }^{54}$ Scottish Executive, Social Inclusion.

${ }^{55}$ Scottish Executive, Better Communities in Scotland; Matthews, 'From area-based initiatives to strategic partnerships', 149; Matthews, 'Being Strategic in Partnership', 464 and 467.

${ }^{56}$ Scottish Executive, Community Planning Advice Note, 10.

${ }^{57}$ Gibb, 'Transferring Glasgow's Council Housing'.

${ }^{58}$ GHA 2006, A Model for a New Strategic Area Regeneration Programme; GCC 2007, Priority Regeneration Areas, A New Approach to Delivery.

59 GHA 2005, Neighbourhood Renewal Strategy 205-07.

${ }^{60}$ Simpson et al, An Evaluation of Play Parks and Multi-purpose Play Areas, 3.

${ }^{61}$ Hexagon, GHA/GCC Land Services Joint Play Area Improvement Programme

${ }^{62}$ Simpson et al, An Evaluation of Play Parks and Multi-purpose Play Areas.
} 
A survey of 4,300 adult residents in fifteen social housing areas across the city in 2011 by the GoWell research programme showed that resident satisfaction with parks and open spaces was higher at $62 \%$ than satisfaction with children's play areas at $46 \% .{ }^{63}$ The same survey also showed that only around a third of residents in most areas rated youth and leisure services as 'good', receiving the lowest ratings for quality of any amenities. ${ }^{64}$ The interim evaluation of the play area improvement programme was generally positive in that local housing staff were of the view that the improved play areas had increased activity levels, while residents considered that the programme had provided activities and facilities for children in safe places, especially for children living in high flats. On the other hand, some residents thought the play areas lacked imagination. ${ }^{65}$ Children valued having play areas for exercise and socialising with friends, and to stop them getting 'bored' or 'sad', although, some wanted play areas to be closer to home. They also argued for supervision and maintenance of play areas, to prevent bullying and help them feel safe, to prevent vandalism and for organised activities. ${ }^{66}$ This was a remarkable continuity with the findings of social researchers in the 1960 s.

In 2005 McAdam also attempted to audit a quarter of the 573 play areas provided by or maintained by the council. . ${ }^{67}$ She found that 'almost $30 \%$ of the sites visited were either removed or under substantial renovation, or in some cases, there was no sign of a play area at all ${ }^{68}$, thus indicating a lack of attention to the administration and supervision of the sites. While the most deprived areas in the city had more play areas on average than the least deprived, there was no clear pattern of provision by deprivation once the population of resident children was taken into account (Figure 3). In addition, the quality of the play areas was worse in the most deprived areas, these having more litter and glass, broken benches, inadequate safety surfacing, broken or missing parts, and rust on equipment.

\footnotetext{
${ }^{63}$ GoWell resident survey 2011. See GoWell, Housing outcomes over time.

${ }^{64}$ Bond et al, 'GoWell'

${ }^{65}$ Simpson et al, An Evaluation of Play Parks and Multi-purpose Play Areas.

${ }^{66}$ Simpson et al, An Evaluation of Play Parks and Multi-purpose Play Areas.

${ }^{67}$ McAdam, 'The Socio-economic Variations in the Provision, Quality and Perception of Play Areas in Glasgow', 241.

${ }^{68}$ McAdam, 'The Socio-economic Variations in the Provision, Quality and Perception of Play Areas in Glasgow', 102.
} 


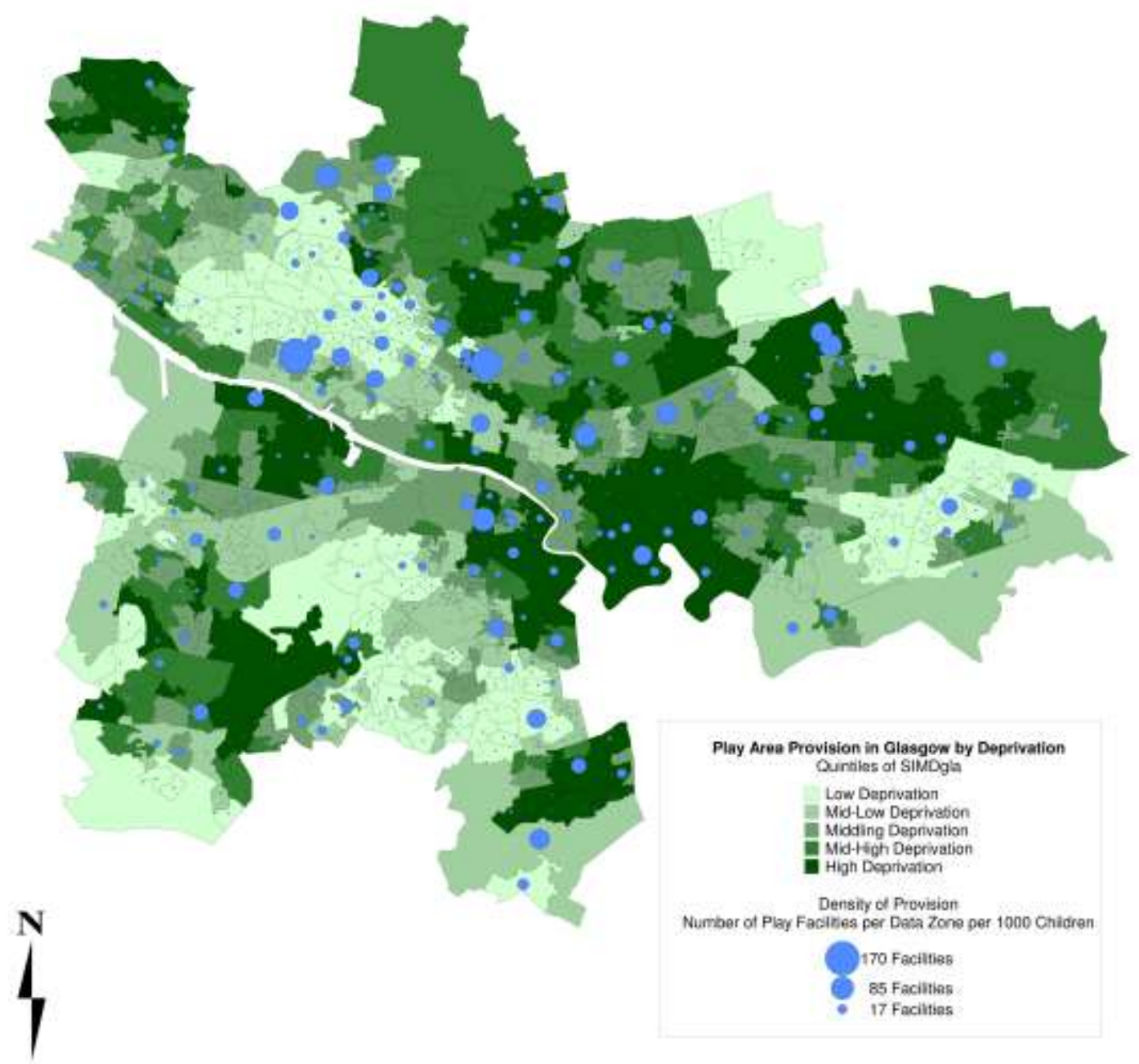

Figure 3: Density of play areas per 1,000 children, across quintiles of deprivation for Glasgow. Source: McAdam 2009.

Yet, as Figures 4, 5 and 6 illustrate in at least three high rise estates play areas have remained in situ in various stages of dereliction since construction in the $1960 \mathrm{~s} / 70 \mathrm{~s} .{ }^{69}$

\footnotetext{
${ }^{69}$ Notably both of these two high rise estates are currently undergoing refurbishment.
} 


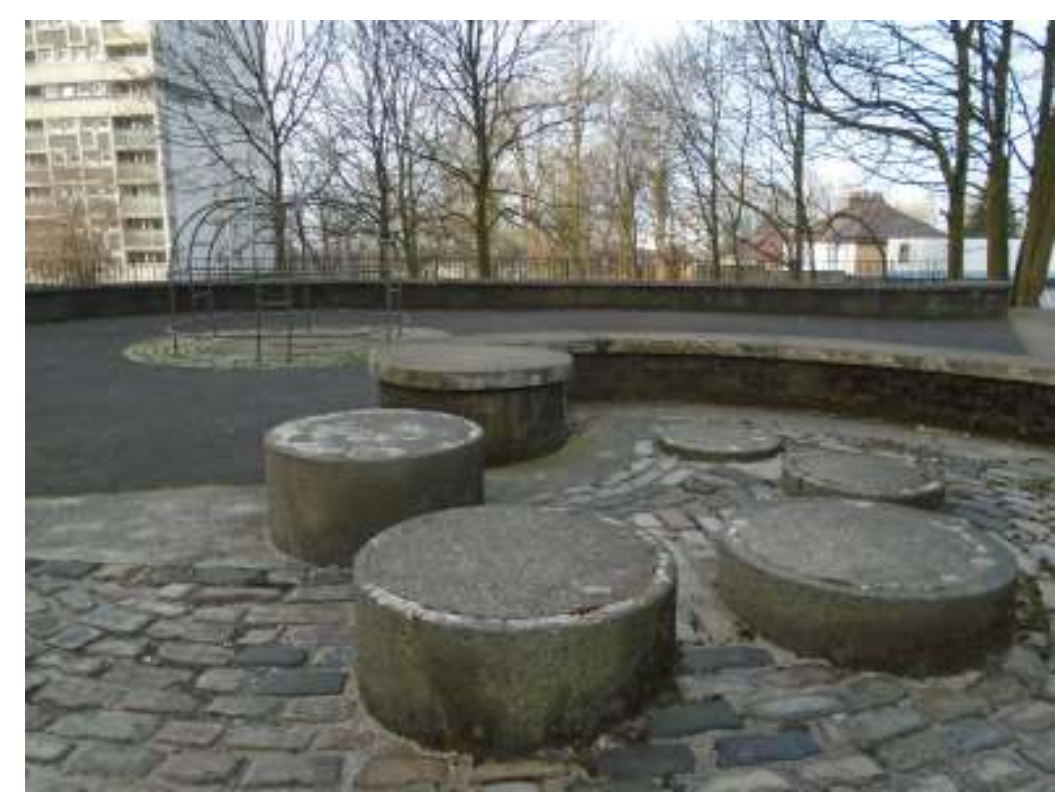

Figure 4: Playground at Broomhill high flats, Glasgow, June 2015

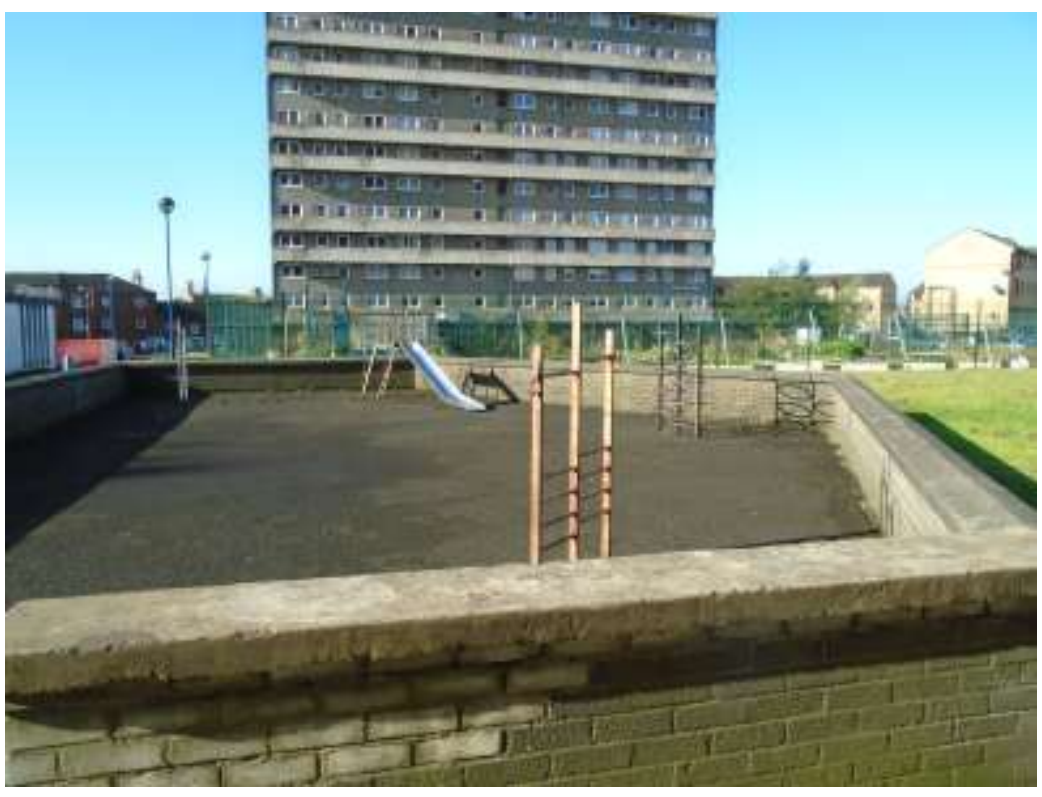

Figure 5: Playground at Cedar Court high flats, Glasgow, October 2015 


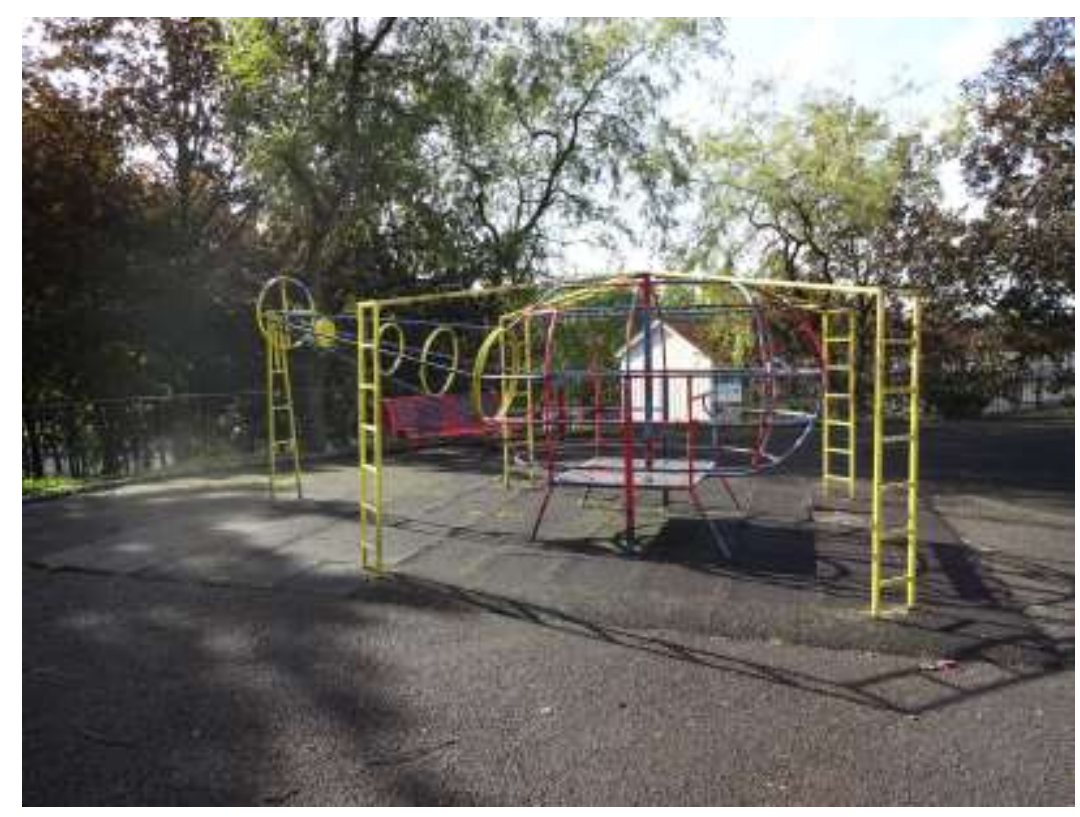

Figure 6: Playground at Moss Heights high flats, Glasgow, April 2016

In the 1990s and early 2000s we see echoes of the past and repeated shortcomings. While the planning of services and amenities moved into the realm of partnerships between public, quasipublic and third sector organisations, and community involvement was seen as central, communication was with adult representatives rather than children, despite international developments in children's rights and participation at this time. ${ }^{70}$ The events-led approach to city wide regeneration also continued with the development of a city marketing bureau in 2004 to attract tourists, conferences and sports meetings to the city. ${ }^{71}$ In this regard, selling Glasgow's image as the 'Dear Green Place' was important so that the upkeep and development of the city's main parks was perhaps the priority rather than caring for, or making, additional local provision for outdoor play. Access to such parks and open spaces was also very uneven and dependent on the ability to travel as determined by financial resources and the age of the child.

\section{Current Policy and Practice for Play in Scotland and Glasgow}

Since the first majority government in the Scottish Parliament was elected in 2011, a great deal of policy development has been undertaken in relation to children and play, though few standards or means of provision have been proposed. Instead there has been a greater involvement of voluntary and community organisations in both play and neighbourhood development. For the Scottish Government, community involvement is a key means for improving the quality of places to enhance health and wellbeing, in line with its general community empowerment agenda. ${ }^{72}$ The Scottish Government's emphasis upon the link between places, health and children was expressed in Good Places, Better Health for Scotland's Children in 2011. It talked of ensuring 'the provision, quality and use of greenspace, natural play areas, woodlands and other natural settings' for younger and older

\footnotetext{
${ }^{70}$ Percy-Smith, 'Negotiating active citizenship', 11.

${ }^{71}$ See https://www.glasgow.gov.uk/index.aspx?articleid=19052

${ }^{72}$ Scottish Government and COSLA 2009, Scottish Community Empowerment Action Plan.
} 
children and recommended that children have access to natural greenspaces within $\mathbf{3 0 0}$ metres of their homes. ${ }^{73}$ Informal surveillance by parents was mentioned, though it also recommended 'supporting activities' within these spaces, and 'providing outdoor play and learning opportunities'. However, no recommendations were made as to how this was to be done, nor was any design guidance offered.

This was followed by a Play Strategy for Scotland in 2013, which declared that 'children playing outdoors is something we want to see happening much more in all outdoor places including green space, parks and streets that are valued by the community'. ${ }^{74}$ The Chief Medical Officer for Scotland stated that 'investing in children's play is one of the most important things we can do to improve children's health and wellbeing in Scotland'. ${ }^{75}$ There is an emphasis in the strategy on the importance of interesting design of outdoor spaces and stimulating environments produced in consultation with children. But there is no discussion of how these things would be achieved, and no mention of play parks or play spaces, although there is reference to 'appropriate equipment' ${ }^{76}$ The need for a qualified workforce is also mentioned, though more in terms of providing support and advice to parents and carers (who will in turn provide play opportunities outside formal settings), rather than in relation to acting as supervisors for outdoor play, as requested by parents and children in previous studies. An Action Plan followed in the same year. ${ }^{77}$ However very few 'practical steps' to 'deliver tangible improvements' were set out, apart from committing to 'promote and support the implementation of existing materials for outdoor play audits' by local authorities so as to 'establish a baseline from which they can measure satisfaction levels and deliver improvements'. ${ }^{78}$

Indeed, Glasgow's current Open Space Development Guide refers to its audit of local provision in accord with stated standards for different categories of open space. ${ }^{79}$ The standards include: 0.7 hectares of equipped children's play area per 1,000 people within 300 metres and 0.5 hectares of parks or amenity open space per 1,000 people within 400 metres. If flatted developments are proposed in areas of open space deficiency, or will cause a deficiency against these standards, onsite provision is required, unless the site is unsuitable or the site is near an open space that can be enhanced, in which case a financial contribution to the authority can be made instead. These open space requirements for new developments seem less than watertight and open to flexible interpretation, and do not appear to provide a good means of ensuring any particular level or quality of children's play areas or open spaces across the city. This was evident in a recent dispute in the city where a piece of 'unused' land, North Kelvin Meadow, in Maryhill, had been approved for development as executive flats. Strong opposition from the community has ensured its ongoing use as a children's play area and community green space.$^{80}$ Indeed, there has been criticism of a 'development first' approach in Glasgow. Play Scotland, a political lobbying organisation which is a

\footnotetext{
${ }^{73}$ Scottish Government, Good Places, Better Health for Scotland's Children, 17.

${ }^{74}$ Scottish Government, Play Strategy for Scotland: Our Vision, 20.

${ }^{75}$ Scottish Government, Play Strategy for Scotland: Our Vision, 8.

${ }^{76}$ Scottish Government, Play Strategy for Scotland: Our Vision, 21.

${ }^{77}$ Scottish Government, Play Strategy for Scotland: Our Action Plan, 9.

${ }^{78}$ Scottish Government, Play Strategy for Scotland: Our Action Plan, 6 and 26.

${ }^{79}$ Glasgow City Council 'DG/ENV 2 - OPEN SPACE AND PUBLIC REALM PROVISION' http://glasgow.gov.uk/CHttpHandler.ashx?id=13621\&p=0

${ }^{80}$ For details of the campaign to 'Save North Kelvin Meadow' see https://northkelvinmeadow.com/
} 
key partner in the Scottish Government's strategic approach to play in Scotland ${ }^{81}$, has called for a statutory duty to provide play spaces in Scotland, while others have proposed a move away from 'plastic play parks' to more adventurous wild spaces. ${ }^{82}$ This seems in accordance with Glasgow'splay strategy which talks of 'vibrant places to play' and 'creating opportunities for free play', although both those key terms are undefined and no preferred rates of provision are stated. ${ }^{83}$

While central and local government were working out what play provision they wished to provide for Scotland's children, voluntary organisations, working with precarious short-term funding, stepped in to provide facilities and space for play; two notable examples in Glasgow are Reidvale Adventure Play Association and the Baltic Street Adventure Playground. Reidvale was the creation of local parents with the help of the local, community-led housing association. It was established in 1988 after the housing association helped convert an area of concrete waste ground left over from Glasgow Eastern Area Renewal (GEAR) into a fenced, safe play area for children with both indoor and outdoor equipped play areas, forming 'a fully integrated, safe, supervised playground environment in their local community'. ${ }^{84}$ Like Reidvale, Baltic Street is in the deprived East End of Glasgow and was established in 2013 by the Turner Prize winning art and architecture collective Assemble in cooperation with arts organisation Create. It is described as 'a temporary and direct response to the lack of play space and out of school provision' for children and families in Dalmarnock', which follows the ethos of the 'junk playgrounds' established in the UK in the immediate post-war years. ${ }^{85}$ The local community were very much involved in helping make the project permanent, subject to funding and children were involved in all decisions, including the appointment of playworkers.

In the latest development in December 2015 the Scottish Government, in partnership with Play Scotland launched 'The Play Map' in order to support Community Planning Partnerships to build play into their strategic plans. This initiative aimed to enable communities to 'deliver on their objectives to support the wellbeing of children, young people and their families across communities'. ${ }^{86}$ Obviously community empowerment is central to 'The Play Map' with objectives including promoting a 'child's right to play', providing leadership to help appoint 'Play Champions' and listening 'to children, young people, families and communities so that their views' inform Community Planning Partnerships. It was also the intention to map existing play provision and explore gaps in current services and opportunities. Such maps would enable a review of the role of play within existing local plans and consider 'effective approaches to developing play in communities'. The desire to 'share effective practice' was notable and highlights the uneven provision for play in Scotland. Glasgow City Council also recently relaunched its play strategy (20162018). This also places an emphasis on Community Planning to stimulate provision of outdoor play facilities. ${ }^{87}$ Currently it is too early to assess the impact of 'The Play Map' and associated initiatives in communities throughout the city. Although it is worth remembering that recent appraisals of

\footnotetext{
${ }^{81}$ For further details see http://www.playscotland.org/who-we-are/

${ }^{82}$ Herald Scotland, 'City children being sold short over the right to play', 31 January 2016

[http://www.heraldscotland.com/news/14242651.City_children_being_sold_short_over_the_right_to_play/]

${ }^{83}$ GCC et al 2011, Playing for Real.

${ }^{84}$ Reidvale Adventure Play Association, http://www.rapa.org.uk/

${ }^{85}$ Baltic Street Adventure Playground, http://www.balticstreetadventureplay.co.uk/background, Hurtwood, Planning for Play.

${ }^{86}$ Elsley, Play Map, 3.

${ }^{87}$ http://www.glasgowlife.org.uk/communities/pages/glasgow\%27s-play-strategy-2016-18.aspx
} 
Community Planning Partnerships have found them to be comparatively weak in engaging with communities, although better at coordinating services in relation to regeneration. ${ }^{88}$

\section{Discussion: Ineffective Policy?}

Over the last seventy years, a number of continuities can be identified in relation to the planning and provision of outdoor play facilities for children in Glasgow, particularly those living in public sector housing. Perhaps the first thing to observe is that the majority of adult residents and parents have been dissatisfied with play provision at all periods of time; the views of children are less often collected, but reveal a lack of enthusiasm for existing play areas seen as 'boring', and concerns about safety, incivilities and vandalism. ${ }^{89}$ Parental concerns about the safety of children playing out have not been addressed whenever outdoor play space is provided; calls for supervision of outdoor play have mostly gone unheeded, reflecting a general pattern of one-off capital expenditures, without provision for ongoing revenue spend. Where play spaces have been provided, they have not been maintained very well, and have usually run into disrepair and disuse, no matter who owns them. ${ }^{90}$

At various times over the past seventy years, policy has focused on one or more of five key elements, but never considered all together: space standards for play; design guidelines; levels of capital expenditure; levels of maintenance expenditure; and, supervision arrangements. There are also continuities in terms of the notable community and voluntary sector involvement in play provision, often in response to inadequate local authority provision, but without adequate recognition or support. In 1968 Lady Allen of Hurtwood, who had first imported the idea of 'junk' playgrounds from Denmark, suggested that the best way to organise such playgrounds would be a partnership between voluntary organisations and local authorities, with the former taking responsibility for administration and running the playgrounds while the local authority would be responsible for contributing at least 85 percent of the capital cost and administrative expenses. ${ }^{91}$ The same model could be applied to all outdoor play facilities, however no such arrangements to encourage inter-sectoral collaboration for children's play have been forthcoming in Glasgow, even though there has been a growing reliance over time on such voluntary provision.

This review of outdoor play provision for children in Glasgow over the long term represents an example of repeatedly ineffective public policy. Policies for play in this context have had several weaknesses in terms of successful programming or implementation.. ${ }^{92}$ First, the aims and objectives for children's play have tended to consist of vague descriptions of desirable circumstances, such as 'supporting children's right to play'. Such descriptions or policy values have not been converted easily into concrete formulations that 'define the status to be attained' or enforced. ${ }^{93}$ In other words, there was no clearly set out description of the level, type or quality of children's outdoor play provision that policy wishes to achieve across a given area. Second, the necessary policy instruments

\footnotetext{
${ }^{88}$ Matthews, 'Being Strategic in Partnership', 464 and 467

${ }^{89}$ McAdam, 'The Socio-economic Variations in the Provision, Quality and Perception of Play Areas in Glasgow', 157.

90 McAdam, 'The Socio-economic Variations in the Provision, Quality and Perception of Play Areas in Glasgow'.

${ }^{91}$ Hurtwood, Planning for Play, 63.

92 Knoepfel et al, Public Policy Analysis.

${ }^{93}$ GCC et al, Playing for Real 21; Knoepfel et al, Public Policy Analysis, 154.
} 
and resources were often absent: there was no public programme for children's play spaces to which resources were allocated, and the only identifiable policy instrument has been the open space guidelines applicable to new developments rather than retrospectively to existing developments. Moreover such guidelines exhibit several of the common problems for the achievement of public policy goals, especially through regulation. ${ }^{94}$ Often it was/is difficult to understand how the rules apply to any given development and there was/is lack of incentives or pressure to comply.. Also, where local authorities aim to achieve policy goals through bargaining with private developers, the latter often prove to be the better negotiators. ${ }^{95}$ Third, in relation to the allocation of space or provisions for play the 'procedural elements' of policy which allocate roles, powers and responsibilities were lacking, hence the call for a statutory duty to provide children's play spaces to be introduced. ${ }^{96}$ Until recently, it was not clear who, if anyone, can be held accountable for the lack of coherent provision. Through its 'Play Map' the Scottish Government aims to close this gap and provide an avenue through which play can become central to Community Planning Partnerships but the success of this initiative has yet to be tested.

In addition, policies require to be evaluated so that information can be routinely collected to monitor progress; this as noted is one of the main aims of the 'Play Map'. At the launch in 2015 it was envisaged that play spaces in local areas would be mapped and using the Getting it Right for Play Toolkit Community Planning Partnerships would record the use of facilities in their areas, 'what they do well and where there are gaps'. This would in turn enable 'benchmarking across Scotland' and allow the measurement of improvement in play. ${ }^{97}$ This data is yet to be made publicly available. Indeed it is unclear exactly what data is being collected in terms of its focus and format e.g. if play spaces were to be enumerated, what counts as a play space? If usage were to be monitored, how should this be measured and for whom? This has been, and is, not the only obstacle to evidencebased-policy in this field. ${ }^{98}$ There has been a lot of research on children's play over the years but it has not identified the relative effectiveness of different approaches to children's play in order to say 'what works'. While recommendations for the future provision of children's play spaces were made (especially in the earlier periods under consideration) these were rarely acted upon. The research was, and perhaps still is, easy to ignore. It was, and remains, difficult to design successful policies based upon such evidence. ${ }^{99}$ Here it can be hoped that data generated by the 'Play Map' may succeed where previous ventures have failed to make an impact.

The persistence of ineffective policy in this area over a seventy year period partly reflects the difficulty of knowing how to get things right in relation to children's outdoor play, but it also reflects a lack of priority afforded the issue in social and political terms. Although children can be treated as full- or near-full citizens at a national level - with a Cross-Party Group on Children and Young People within the Scottish Parliament - at a local level they can still be treated as 'less than citizens'. ${ }^{100}$ Local authorities are reluctant to invest in services - such as children's play - without incentives, requirements or political or public pressure to do so. In the case of Glasgow this may be attributed

\footnotetext{
94 OECD, Reducing the Risk of Policy Failure.

${ }^{95}$ Crook and Whitehead 2002, Social housing and planning gain.

${ }^{96}$ Herald Scotland, 'City children being sold short over the right to play'.

${ }^{97}$ Elsley, Play Map, 3.

${ }^{98}$ Head, Reconsidering Evidence Based Policy.

99 House of Lords Science and Technology Committee, Behaviour Change.

${ }^{100}$ Percy-Smith, 'Negotiating active citizenship', 11.
} 
to the financial pressures placed upon the City Council in times of public funding budget cuts. Nevertheless, children's outdoor play has suffered from being less of a priority, or the poor cousin, of other areas of policy intervention relating to children, such as: school-based physical education, for which there are stipulated expectations and policy supports, including an Active Schools programme; ${ }^{101}$ and sports participation, particularly in the years leading up to and since the Commonwealth Games 2014 in Glasgow. ${ }^{102}$

\section{Conclusion}

We have established the repeated deficiencies that have made play policy ineffective in different periods in Glasgow's history. The explanation for this lies in the politics and cultural image of the city. In other words Glasgow City Council's (previously Glasgow Corporation) self-image historically affected the provision of play in the city and continues to do so today. The planning system in the city has facilitated housing developments without adequate play provision from the 1950s to the present day. The provision of improved housing has remained the continual priority throughout, rather than 'secondary' amenities. This was not surprising given Glasgow's history of overcrowding and the ongoing negative effects of deindustrialisation on the city's economy. In tandem with this has been the city's pride in, and reliance on, large urban parks, in contrast to the general neglect of small, local outdoor play spaces. This focus on Glasgow as the 'Dear Green Place' has assisted housing developers and neatly ties in with the City Council's strategic promotion of the city for tourism, conferences and sports events. Moreover the city's municipal authorities have controlled and dominated the provision of play facilities throughout the period under consideration with the resulting lack of agency and input from children or community groups in the city. Thus while voluntary organisations are able to provide outdoor play facilities, such as Reidvale and Baltic Street, there is no formal partnerships in Glasgow between the Council and such voluntary community organisations as proposed by Lady Marjorie Allen of Hurtwood in 1968. This may be due to the continuing focus on school and sports clubs as an avenue for improving the physical activity of children, within which sport, rather than play, takes priority. Perhaps Glasgow's success in attracting international sports events to the city and the need to evidence legacy from said events is influential too.

Nevertheless, there have been two recent developments which have the potential to help bring about improvements in the planning and provision of outdoor play for children in Glasgow and Scotland. First, child obesity and low activity indicators are gaining more public and political attention, and this brings attention to children's environments. ${ }^{103}$ In 2014, 31\% of children under 16 in Scotland were at risk of being overweight, including $17 \%$ who were medically obese, and $24 \%$ who did not meet physical activity recommendations. ${ }^{104}$ Moreover, research on young children (aged up to 6) in Scotland has recently shown that not being active at the recommended level per day is associated with not having access to a local playground or park or a local swimming pool, while

\footnotetext{
${ }^{101}$ Active Schools Programme http://www.gov.scot/Topics/Education/Schools/HLivi/PE

${ }^{102}$ Clark and Kearns, 'Pathways to physical activity legacy'.

${ }^{103}$ Scottish Government, Preventing Overweight and Obesity in Scotland.

${ }^{104}$ Scottish Government, Obesity Indicators.
} 
being highly sedentary is associated with low quality green spaces. ${ }^{105}$ Second, the current emphasis upon 'place-making' within planning is coupled with a political appetite in Scotland for 'community empowerment', which offers the opportunity for communities to press and take action for improvements in children's environments, including play and outdoor spaces for children. The recently passed Community Empowerment (Scotland) Act 2015 introduces three relevant changes: a requirement for Community Planning Partnerships to support community groups to engage in community planning, 'particularly in disadvantaged areas' (including engagement with the 'Play Map'); the right for a community body to request that a service be improved or to help improve it; and processes for community purchase in the public interest of buildings or land which are up for sale, and a community right to buy abandoned or neglected land. ${ }^{106}$ We must wait to see if communities, particularly with child involvement, use these powers extensively to retain or improve outdoor play spaces for children (as in the case of the North Kelvin Meadow), though children and youth organisations are the most common focus for adult volunteering in Scotland. ${ }^{107}$ As a result there is perhaps hope that voluntary groups in cooperation with local authorities, the Scottish Government and lobbying organisations will be able to overcome the barriers to outdoor play for all children in Scotland and Glasgow of a variety of backgrounds. If Scottish and Glaswegian children were encouraged and supported in being 'outdoor children' the implications for health and wellbeing for the future would be profound.

\section{Bibliography}

Bond, Lyndal, Egan, Matt, Kearns, Ade, and Tannahill, Carol. 'GoWell: The challenges of evaluating regeneration as a population health intervention.' Preventive Medicine, 57, no. 6 (2013): 941-947.

Cambridge Policy Consultants. An evaluation of the New Life for Urban Scotland initiative in Castlemilk, Ferguslie Park, Wester Hailes and Whitfield. Edinburgh: Scottish Executive, 1999.

Clark, Julie and Kearns, Ade. 'Pathways to physical activity legacy: Assessing the regeneration potential of multi-sport events using a prospective approach', Local Economy, (2015 online first).

Collins, Chik and Levitt, lan. 'The 'Modernisation' of Scotland and its Impact on Glasgow, 1955-1979: 'Unwanted Side Effects' and Vulnerabilities' Scottish Affairs, 25:3(2016), 294-316.

Cradock, A.L., Kawachi, I., Colditz, G.A., Hannon, C., Melly, S.J., Wiecha, J.L., \& Gortmaker, S.L. (2005). Playground safety and access in Boston neighborhoods. American Journal of Preventive Medicine, 28(4), 357-363.

Crawford, Fiona, Beck, Sheila and Hanlon, Phil, Will Glasgow Flourish? Glasgow: Glasgow Centre for Population Health, 2007.

Crook, Anthony and Whitehead,Christine. 'Social housing and planning gain: is this an appropriate way of providing affordable housing?' Environment \& Planning A, 34, 1259-1279, 2002.

\footnotetext{
${ }^{105}$ Parkes et al, Growing Up in Scotland.

${ }^{106}$ SCDC, The Community Empowerment (Scotland) Act.

${ }^{107}$ Scottish Government, Scotland's People.
} 
Cullingworth, Barry. and Nadin, Vincent. Town and Country Planning in the UK $13^{\text {th }}$ Edition. London: Routledge, 2002.

Farmer, Elspeth and Smith, Roger. 'Overspill Theory: A Metropolitan Case Study', Urban Studies, 12(1975), 151-68.

Forrest, Ray and Murie, Alan. 'Residualisation and council housing: aspects of the changing social relations of housing tenure'. Journal of Social Policy, 12(4), 453-468, 1983.

Glasgow City Council. Priority Regeneration Areas. A New Approach to Delivery. Glasgow, GCC, 2007. Glasgow City Council, Glasgow Life and NHS Greater Glasgow \& Clyde. Playing for Real: Glasgow's Play Strategy 2011-14. Glasgow: GCC, 2011.

Glasgow Corporation Architectural and Planning Department. City of Glasgow Development Plan: quinquennial review, Glasogow: Glasgow Corporation Architectural and Planning Department, 1960. Glasgow Housing Association. A Model for a New Strategic Area Regeneration Programme. GHA, Glasgow: GHA, 2006.

Glasgow Housing Association. Neighbourhood Renewal Strategy 2005-07 Strategy and Action Plan. Glasgow, GHA, 2005.

Gibb, Kenneth. 'Transferring Glasgow's Council Housing: Financial, Urban and Housing Policy Implications.' European Journal of Housing Policy, 3, no. 1 (2003): 89-114.

Gittus, Elizabeth. Flats, Families and the Under Fives. London: Routledge and Kegan Paul, 1976.

GoWell, Housing outcomes over time: A comparison across the 2006, 2008 and 2011 GoWell community surveys. Glasgow, GoWell, 2013.

Head, Brian W. 'Reconsidering Evidence-based Policy: Key Issues and Challenges.' Policy and Society, 29 (2010): 77-94.

Hexagon Research and Consulting. GHA/GCC Land Services Joint Play Area Improvement Programme, Evaluation of LHO and Residents' Views, Report of the Executive Summary, November 2008.

Hole, Vere. Children's play on housing estates. London: H.M.S.O., 1966.

Horsey, Miles. Tenements and towers: Glasgow working-class housing 1890-1990. Edinburgh:

RCHAMS, 1990.

House of Lords Science and Technology Committee. Behaviour Change, Second Report of Session 2010-11. London: HMSO, 2011.

Hurtwood, Lady Marjory Allen of. Planning for Play. London: Thames and Hudson, 1968.

Jephcott, Pearl and Robinson, Hilary. Homes in High Flats: some of the human problems involved in multi-storey housing. Edinburgh: Oliver \& Boyd, 1971. 
Karsten, Lia. 'It all used to be better? Different generations on continuity and change in urban children's daily use of space.' Children's Geographies, 3, No. 3 (2005) 275-290.

Knoepfel, Peter, Larrue, Corinne, Varone, . Frédéric and Hill, Michael. Public Policy Analysis. Bristol: Policy Press, 2007.

Lever, W.F. 'Deindustrialisation and the reality of the postindustrial city', Urban Studies, 28(6): 983999.

Littlewood, Judith and Tinker, Andrea. Families in flats. London: H.M.S.O., 1981.

Lowry, Stella. 'Families and flats.' British Medical Journal, 300 (1990): 245-247.

Maizels, Joan. Two to Five in High Flats: An enquiry into play provision for children aged two to five years living in high flats. London: Housing Centre Trust, 1961.

Mansley, R. D. Development Plan Review: Planning Standards for Housing Layout. Glasgow: Corporation of Glasgow, 1971.

Maver, Irene. Glasgow. Edinburgh: Edinburgh University Press, 2000.

Matthews, Peter. 'From area-based initiatives to strategic partnerships: Have we lost the meaning of regeneration?' Environment and Planning C: Government and Policy, 30 (2012): 147-161.

Matthews, Peter. 'Being Strategic in Partnership - Interpreting Local Knowledge of Modern Local Government.' Local Government Studies, 40, No. 3 (2014): 451-472.

McAdam, Chloe. The socio-economic variations in the provision, quality and perception of play areas in Glasgow, PhD thesis. Glasgow: University of Glasgow, 2009.

Ministry of Housing and Local Government. Homes for Today and Tomorrow. London: H.M.S.O., 1961.

NHS Greater Glasgow and Clyde. Child Healthy Weight. Board Paper No. 2011/24. Glasgow: NHSGGC, 2011.

OECD. Reducing the Risk of Policy Failure: Challenges for Regulatory Compliance. Paris: OECD, 2000.

O'Toole, Mo, Snape, Dawn, and Stewart, Murray. Interim Evaluation of the Castlemilk Partnership. Edinburgh: Scottish Office, Central Research Unit, 1995.

Parkes, Alison., Sweeting, Helen and Wight, Daniel. Growing Up in Scotland: Overweight, Obesity and Activity. Edinburgh: Scottish Government, 2012.

Percy-Smith, Barry. 'Children's Participation in Local Decision Making: The Challenge of Local Governance'. In Stepping forward: children and young people's participation in the development process edited by Johnson, V., Ivan-Smith, E., Gordon, G., Pridmore, P. and Scott, 225-229. Bradford: ITDG Publishing, 1998. 
Percy-Smith, Barry. 'Negotiating active citizenship: Young people's participation in everyday spaces.' In Politics, Citizenship and Rights. Geographies of Children and Young People (7) edited by Kallio, Kirsi Pauliina, Mills, Sarah, and Skelton, Tracey. London: Springer, 2015.

PIEDA, GEAR Project Evaluation: Final Report. Edinburgh, 1988.

Rae, James H. Planning Policy Report : Open Space and Recreation. Glasgow: Planning Department, 1975.

Richman, Naomi. 'The Effects of Housing on Pre-school Children and their Mothers.' Development of Medicine and Child Neurology, 16 (1974): 53-58.

Satsangi, M, Malcolm, J and Maclennan, Duncan. House condition survey 1985: Vol. 2- people and dwellings, the household survey. Glasgow: Glasgow University Centre for Housing Research, 1990.

Scottish Community Development Centre. The Community Empowerment (Scotland) Act, SCDC Briefing no. 2/15. Glasgow: SCDC, 2015.

Scottish Government. Preventing Overweight and Obesity in Scotland: A Route Map Towards Healthy Weight. Edinburgh: Scottish Government, 2010.

Scottish Government. Good Places, Better Health for Scotland's Children: Prepared by the Evaluation Group of Good Places Better Health. Edinburgh: Scottish Government, 2011.

Scottish Government. Play Strategy for Scotland: Our Vision. Edinburgh: Scottish Government, June 2013.

Scottish Government, Scotland's People: Annual Report Results from 2013 Scottish Household Survey. Edinburgh: Scottish Government, 2014.

Scottish Government. Obesity Indicators: Monitoring Progress for the Prevention of Obesity Route Map-November 2015 Report. Edinburgh: Scottish Government, 2015.

Scottish Government and COSLA. Scottish Community Empowerment Action Plan - Celebrating Success: Inspiring Change. Edinburgh: Scottish Government, 2009.

Scottish Office. Progress in Partnership: A Consultation Paper on the Future of Urban Regeneration Policy in Scotland. Edinburgh: Scottish Office, 1993.

Scottish Office. Social Inclusion: Opening the Door to a Better Scotland. Edinburgh: Scottish Office, 1999.

Simpson, Scott, Morrison, Colin, and Fraser, Yvonne. An Evaluation of Play Parks and Multi-purpose Play Areas. The TASC Agency: January 2009.

Smith, Roger, East Kilbride: the biography of Scottish new town, 1947-1973. London: HMSO, 1979.

Smith, Roger, 'The Origins of Scottish New Towns Policy and the Founding of East Kilbride', Public Administration 52:2(1974): 143-59. 
Suecoff, S.A., Avner, J.R., Chou, K.J., \& Crain, E.F. 'A comparison of New York City playground hazards in high- and low-income areas'. Archives of Pediatrics and Adolescent Medicine, 153:4(1999): 363-66.

Thomson, Mathew. Lost Freedom: The Landscape of the Child and the British Post-war Settlement. Oxford: Oxford University Press, 2013.

Valentine, Gill and McKendrick, John. 'Children's outdoor play: exploring contemporary parental concerns about children's safety and the changing nature of childhood.' Geoforum 28(1997): 1-17.

van Vliet, Willem and Karsten, Lia. 'Child-Friendly Cities in a Globalizing World: Different Approaches and a Typology of Children's Roles.' Children, Youth and Environments 25, No. 2, Child-Friendly Cities: Critical Approaches (2015): 1-15.

Veitch, Jenny, Bagley, Sarah, Ball, Kylie and Salmon, Jo. 'Where do children usually play? A qualitative study of parents' perceptions of influences on children's active free-play.' Health \& Place 12:4(2006): 383-393.

Walsh D, Bendel N, Jones R, Hanlon P. 'It's not 'just deprivation': why do equally deprived UK cities experience different health outcomes?' Public Health 124:9(2010): 487-495.

Walsh D, McCartney G, Collins C, Taulbut M, Batty G C, History, politics and vulnerability: explaining excess mortality in Scotland and Glasgow. Glasgow: Glasgow Centre for Population Health, May 2016.

Wannop, Urlan. 'The Glasgow Eastern Area Renewal (GEAR) Project: A Perspective on the Management of Urban Regeneration.' The Town Planning Review, 61, No. 4 (1990), 455-474.

Webster, D and Purkiss, E. House Condition Survey 1985 Volume 3; the District Council's housing stock. Glasgow: Glasgow District Council (Dept. of Housing), 1990.

Willis, Margaret (Central Housing Advisory Committee). Living in Flats: Report of the Flats Subcommittee of the Central Housing Advisory Committee. London: H.M.S.O., 1952. 